\title{
Experimental investigation of diesel engine with water injection system on emission parameters
}

\author{
Sagar Patel ${ }^{1}$, Gaurav P Rathod ${ }^{2}$, Tushar M Patel $^{3}$ \\ ${ }^{I}$ (ME Scholar, Department of Mechanical Engineering, KSV University, Gujarat,India) \\ ${ }^{2}$ (Assistant Professor, Department of Mechanical Engineering, KSV University,Gujarat,India) \\ ${ }_{3}^{3}$ (Associate Professor, Department of Mechanical Engineering, KSV University,Gujarat,India)
}

\begin{abstract}
The concept of water addition to the IC engine has been around for over 50 years. Diesel engines are nominated for highly emission producer like $\mathrm{NO} x, \mathrm{CO}, \mathrm{CO}_{2}$ and $\mathrm{HC}$. These emissions are highly depending upon the combustion chamber temperature which is exceeding up to $750 \mathrm{~K}$. Therefore by controlling peak combustion chamber temperature NOx formation can be controlled effectively. The latent heat of evaporation of water is $2256 \mathrm{~kJ} / \mathrm{kg}$. In the study, water injection method is applied to a Single cylinder diesel engine to control NOx emissions. Water injected in intake manifold of diesel engine is by using calibrated burette. For Constant compression ratio, 9, 16, 38ml/min water mass supply to engine. Results are observed for 1 to 8 load condition. The obtained results are compared with conventional diesel engine in terms of $\mathrm{NO} x, \mathrm{CO}, \mathrm{CO}_{2}, \mathrm{HC}$ emissions. In the experimental results, it is determined that the engine $\mathrm{NOx}$, decreased and $\mathrm{CO}, \mathrm{CO}_{2}, \mathrm{HC}$ increased.
\end{abstract}

Keywords: Diesel engine, Water injection, Engine Emission, $\mathrm{NO}_{x}$, Fumigation.

\section{Introduction}

Among most two type internal combustion engine diesel engine generate more undesirable emission during combustion process. The pollutants are directly affecting atmosphere and cause problems such as global warming, acid rain, smog, respiratory hazards etc. These emissions are mostly due to dissociation of nitrogen, nonstoichometric combustion, major emissions include oxides of nitrogen $\left(\mathrm{NO}_{\mathrm{X}}\right)$, unburnt hydrocarbons $(\mathrm{HC})$, oxides of carbon $\left(\mathrm{CO}, \mathrm{CO}_{2}\right)$. There are various way to control theses pollutants. Two major ways are: control process in to the combustion cylinder and after treatment outside cylinder. In this experiment water is placed with intake air supplied to engine and emission parameters are studied.

The reduction in NOx, $\mathrm{CO}$ and $\mathrm{CO}_{2}$ is more then $80 \%$ by water scrubbing and air dilution system compare to without system.[1] Fuel consumption also remains constant at no load to high load condition. It was invention of his study that no fuel penalty observed. The change in torque and power at 1200 r.p.m with rate of $20 \%$ steam injection, result also showed minimum SFC and maximum effective efficiency highest NO formation reduce at $1200 \mathrm{rpm}$ with $20 \%$ steam injection and also no inverse effects on $\mathrm{HC}, \mathrm{CO}, \mathrm{CO}_{2}$ are observed [2]. The reduction in the level of both $\mathrm{NO}_{\mathrm{X}}$ and particulate matters (PM), NOx is reduced almost $30 \%$ and $60 \%$ in PM by $15 \%$ water in diesel emulsion. It has only limited effect on $\mathrm{CO}_{2}$ [3]. Water diesel emulsion effects due to the reducing peak temperature of combustion chamber and micro explosion phenomenon. The performed experiment on heavy duty diesel engine with real time water injection (RTWI), RTWI system delivered metered quantity of water to injectors [4]. At tip of injector the initial portion of injection contained mostly diesel fuel. RTWI system has BSFC cost for $1 \%$ NOx reduction is $0.05 \%$ and for other like EGR it is $0.13 \%$, Retarded injection timing $0.4 \%$. It clears that RTWI is cheaper than other techniques.

Based on previous literature reviews Experiment is carried out on single cylinder diesel engine to investigate study of water injection at atmospheric temperature and pressure condition.

\section{Experimental Setup And Technical Method}

Experiments were carried out with single cylinder, four strokes and water cooled, multi fuel research engine. Table and fig-1 shows engine specification and engine setup respectively. To measure brake torque the engine is connected to eddy current type dynamometer for loading. Before start experiments load cell is calibrated accurately. 


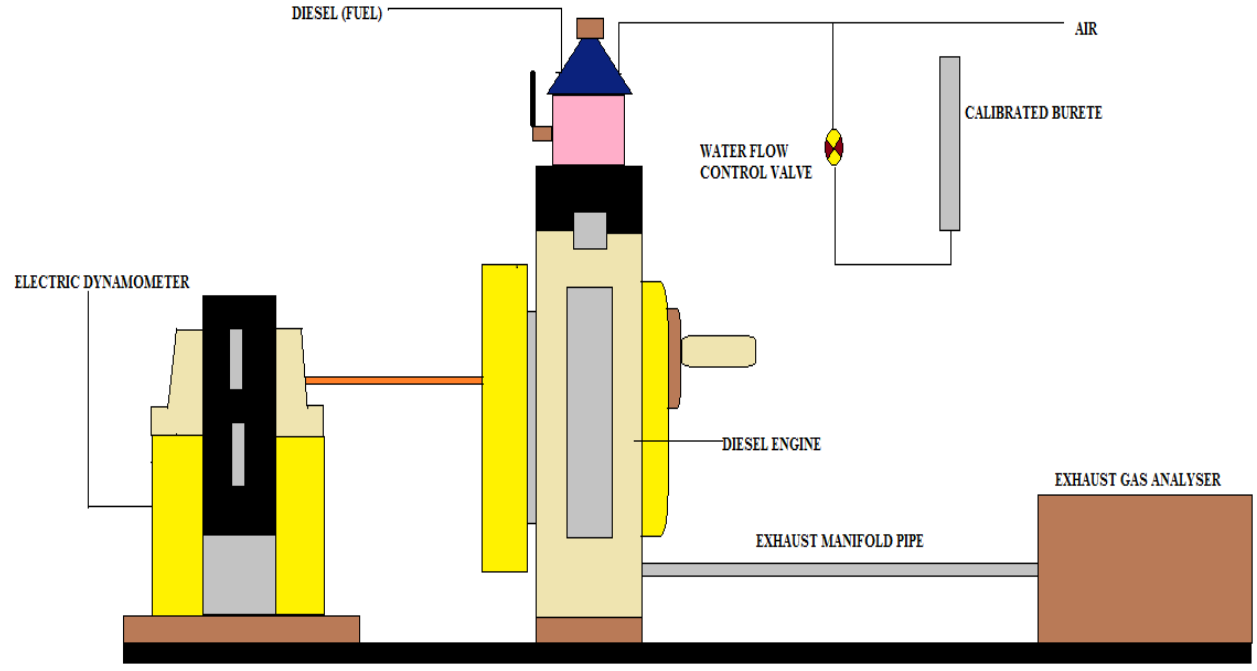

Fig.1 Experimental Setup

\section{Technical Specifications}

\begin{tabular}{|l|l|}
\hline Model & TV1 \\
\hline Make & Kirlosker Oil Engines \\
\hline Type & Four stroke, Water cooled, Diesel \\
\hline No. of cylinder & One \\
\hline Bore & $87.5 \mathrm{~mm}$ \\
\hline Stroke & $110 \mathrm{~mm}$ \\
\hline Combustion principle & Compression ignition \\
\hline Cubic capacity & 0.661 liters \\
\hline Compression ratio 3 port & $17.5: 1$ \\
\hline Lubrication system & Forced feed system \\
\hline
\end{tabular}

In this study QUATTRO PRO, GA4040 type gas analyser was used so as to measure exhausts emission before It use in experiments, device were calibrated. In order to inject water into engine manually controlled water injection system was developed. Water injection system is shown in fig.2.

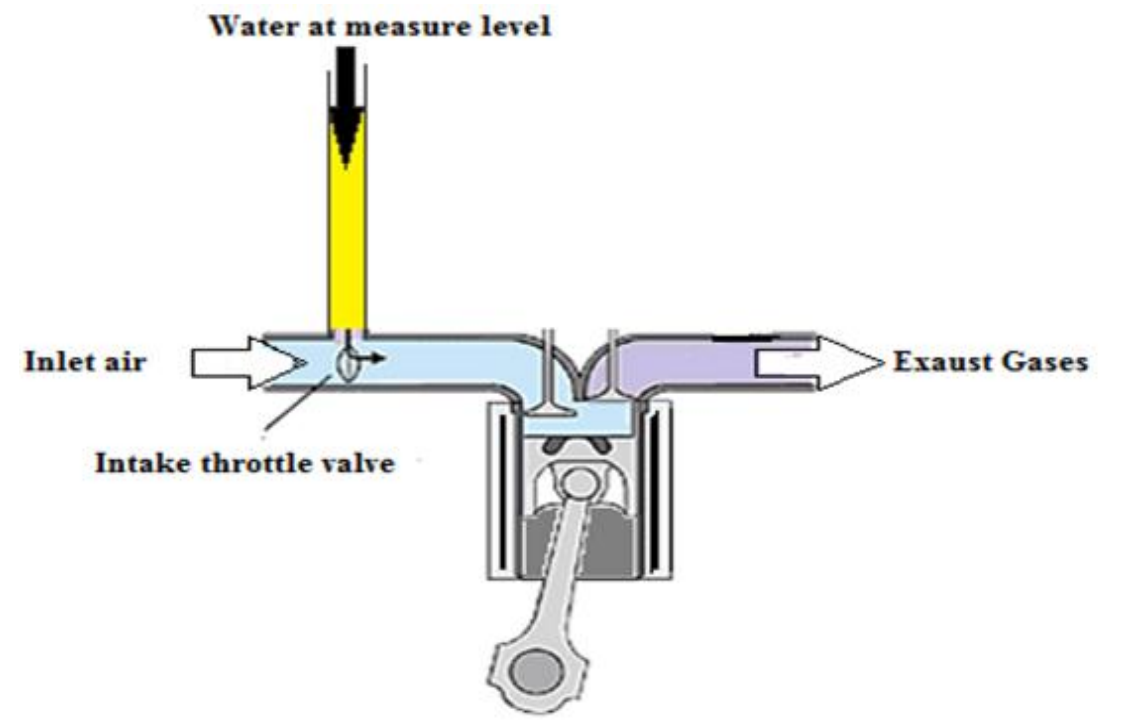




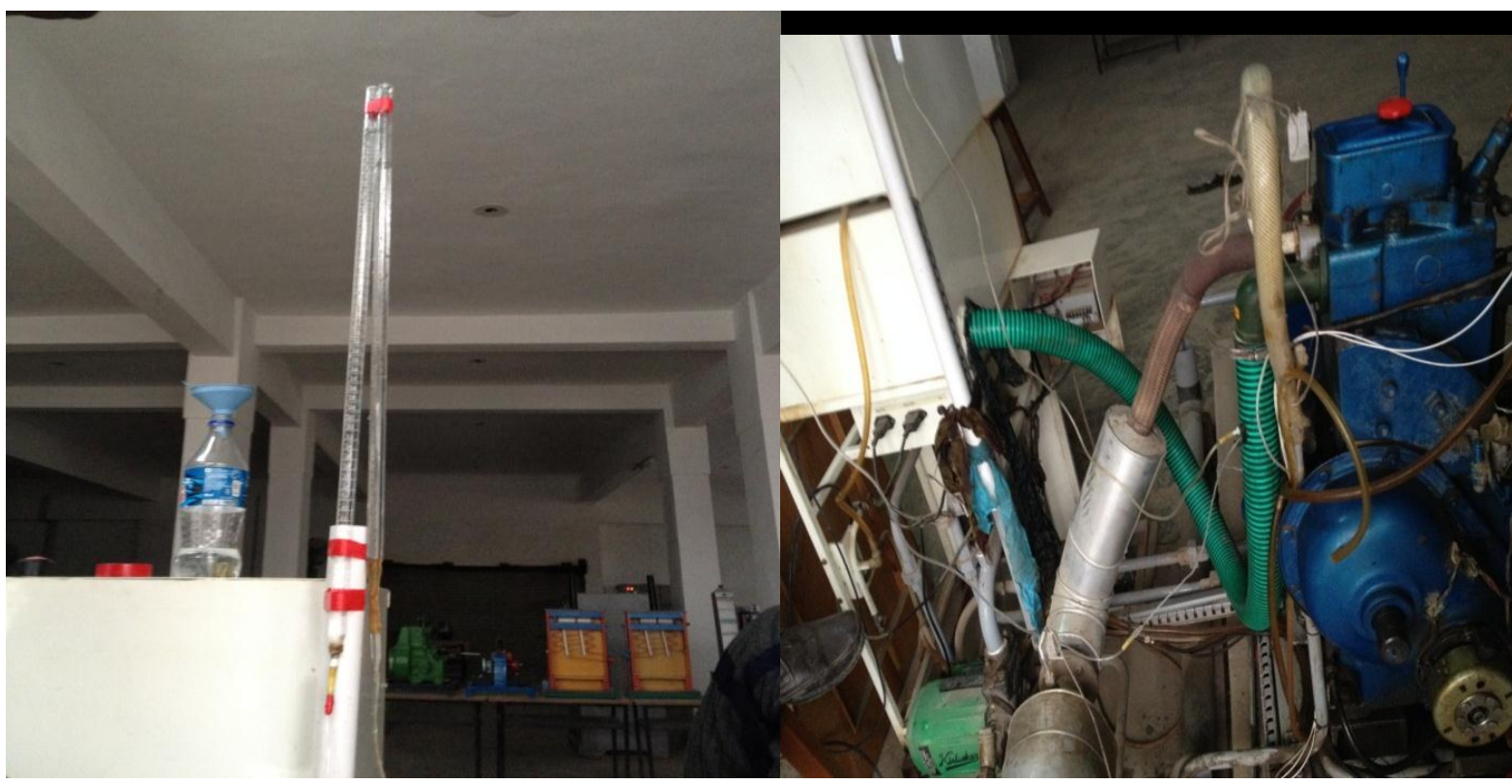

Fig.2 Double burette arrangement for intake manifold water injection system

Experiments were done in variable load 1 to $8 \mathrm{~kg}$ and constant speed condition. In order to compare firstly standard diesel tests were carried out. Then water at atmospheric pressure and temperature was injected with nozzle in intake manifold via water nozzle. Water flow rates $9 \mathrm{ml} / \mathrm{min}, 16 \mathrm{ml} / \mathrm{min}, 38 \mathrm{ml} / \mathrm{min}$ were used. Experiments were repeated for each flow rate and obtained emission values compared with these of standard diesel values.

III. Result And Discussion

\begin{tabular}{|c|c|c|c|c|c|c|c|c|c|c|c|c|c|c|c|c|}
\hline & \multicolumn{4}{|c|}{ Diesel } & \multicolumn{4}{|c|}{$9 \mathrm{ml} / \mathrm{min}$} & \multicolumn{4}{|c|}{$16 \mathrm{ml} / \mathrm{min}$} & \multicolumn{4}{|c|}{$38 \mathrm{ml} / \mathrm{min}$} \\
\hline $\begin{array}{c}\text { Load } \\
\text { (Kg) }\end{array}$ & $\begin{array}{l}\text { CO } \\
(\%)\end{array}$ & $\begin{array}{l}\mathrm{CO}_{2} \\
(\%)\end{array}$ & $\begin{array}{c}\mathbf{H C} \\
(\mathbf{p p m})\end{array}$ & $\begin{array}{c}\mathbf{N O}_{\mathbf{X}} \\
(\mathbf{p p m})\end{array}$ & $\begin{array}{l}\text { CO } \\
(\%)\end{array}$ & $\begin{array}{l}\mathrm{CO}_{2} \\
(\%)\end{array}$ & $\begin{array}{c}\mathbf{H C} \\
(\mathbf{p p m})\end{array}$ & $\begin{array}{c}\mathbf{N O}_{\mathbf{X}} \\
\text { (ppm } \\
\text { ) }\end{array}$ & $\begin{array}{l}\text { CO } \\
(\%)\end{array}$ & $\begin{array}{l}\mathrm{CO}_{2} \\
(\%)\end{array}$ & $\begin{array}{c}\mathrm{HC} \\
\text { (ppm }\end{array}$ & $\begin{array}{c}\mathbf{N O}_{\mathbf{x}} \\
(\mathbf{p p m})\end{array}$ & $\begin{array}{l}\text { CO } \\
(\%)\end{array}$ & $\begin{array}{c}\mathrm{CO} \\
2 \\
(\%)\end{array}$ & $\begin{array}{c}\mathrm{HC} \\
(\mathbf{p p m})\end{array}$ & $\begin{array}{l}\mathbf{N O}_{\mathbf{X}} \\
(\mathbf{p p m}\end{array}$ \\
\hline 1 & 0.12 & 1.21 & 28 & 340 & 0.13 & 1.25 & 30 & 270 & 0.14 & 1.31 & 32 & 145 & 0.15 & 1.4 & 35 & 45 \\
\hline 2 & 0.09 & 1.32 & 31 & 892 & 0.11 & 1.37 & 33 & 480 & 0.13 & 1.42 & 35 & 325 & 0.14 & 1.53 & 38 & 99 \\
\hline 3 & 0.08 & 1.4 & 36 & 1500 & 0.1 & 1.52 & 38 & 590 & 0.11 & 1.68 & 40 & 422 & 0.13 & 1.74 & 43 & 275 \\
\hline 4 & 0.07 & 1.61 & 42 & 2089 & 0.09 & 1.71 & 43 & 1010 & 0.1 & 1.85 & 46 & 712 & 0.12 & 1.9 & 49 & 347 \\
\hline 5 & 0.06 & 1.85 & 43 & 2856 & 0.07 & 1.92 & 45 & 1332 & 0.08 & 2.17 & 49 & 1214 & 0.1 & 2.26 & 51 & 658 \\
\hline 6 & 0.05 & 1.95 & 44 & 3893 & 0.06 & 2.17 & 46 & 1845 & 0.07 & 2.29 & 49 & 1586 & 0.08 & 2.34 & 53 & 905 \\
\hline 7 & 0.04 & 2.11 & 47 & 4532 & 0.05 & 2.23 & 48 & 2232 & 0.06 & 2.34 & 52 & 1841 & 0.07 & 2.46 & 54 & 1245 \\
\hline 8 & 0.03 & 2.19 & 50 & 5608 & 0.04 & 2.31 & 51 & 3206 & 0.05 & 2.39 & 55 & 2927 & 0.06 & 2.47 & 58 & 1409 \\
\hline
\end{tabular}

\section{Nox Formation}

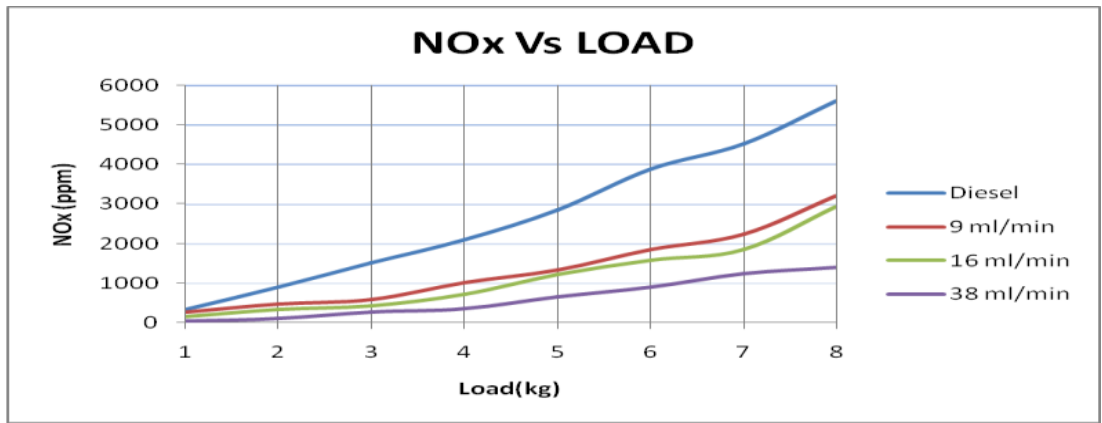

Fig.3 Comparison of $\mathrm{NO}_{\mathrm{X}}$ level 
The comparison of $\mathrm{NO}_{\mathrm{X}}$ formation in cylinder at 1 to $8 \mathrm{~kg}$ load conditions for different water flow rates $9 \mathrm{ml} / \mathrm{min}, 16 \mathrm{ml} / \mathrm{min}$ and $38 \mathrm{ml} / \mathrm{min}$, tested is given in fig-3. As can be seen from the fig water injected caused to decrease $\mathrm{NO}_{\mathrm{X}}$ emissions. The $\mathrm{NO}_{\mathrm{X}}$ emission decrease at all engine loads with increase in water flow rate. The minimum $\mathrm{NO}_{\mathrm{X}}$ is $45 \mathrm{ppm}$ at $1 \mathrm{~kg}$ load with $38 \mathrm{ml} / \mathrm{min}$. According to observed $\mathrm{NO}_{\mathrm{X}}$ emission value change is $4199 \mathrm{ppm}$ at $8 \mathrm{~kg}$ load for $38 \mathrm{ml} / \mathrm{min}$ water flow rate, lowest change is $45 \mathrm{ppm}$ at $1 \mathrm{~kg}$ load $38 \mathrm{ml} / \mathrm{min}$.

It is clear from above result that water in the form of fine spray droplets exerts positive effects on exhaust emission particular to $\mathrm{NO}_{\mathrm{x}}$. The finely atomized water droplets vaporize after injected into combustion chamber. Combined effect of absorbing heat developed by fuel and increased partial pressure of oxygen puts down the combustion temperature and thus it help to decrease formation of $\mathrm{NO}_{\mathrm{X}}$. As can be seen from above fig increase water flow rate give more $\mathrm{NO}_{\mathrm{X}}$ reduction at all load conditions.

\section{$\mathrm{CO}$ and $\mathrm{CO}_{2}$}

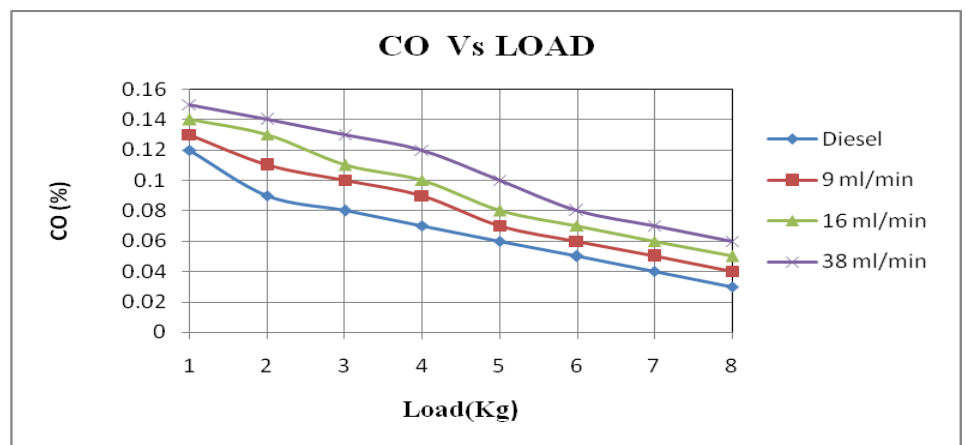

Fig.4 Comparison of CO level

Fig-4 compares $\mathrm{CO}$ emission of water injected diesel engine with standard one. The $\mathrm{CO}$ emission enhance with different water injection rate at all engine loads. Higher water percentage load to incomplete combustion which leads to higher formation of $\mathrm{CO}$ and $\mathrm{CO}_{2}$. The minimum $\mathrm{CO}$ is $0.04 \%$ at $8 \mathrm{~kg}$ load with 9 $\mathrm{ml} / \mathrm{min}$, which is almost near to $0.03 \%$ at standard diesel fuel.

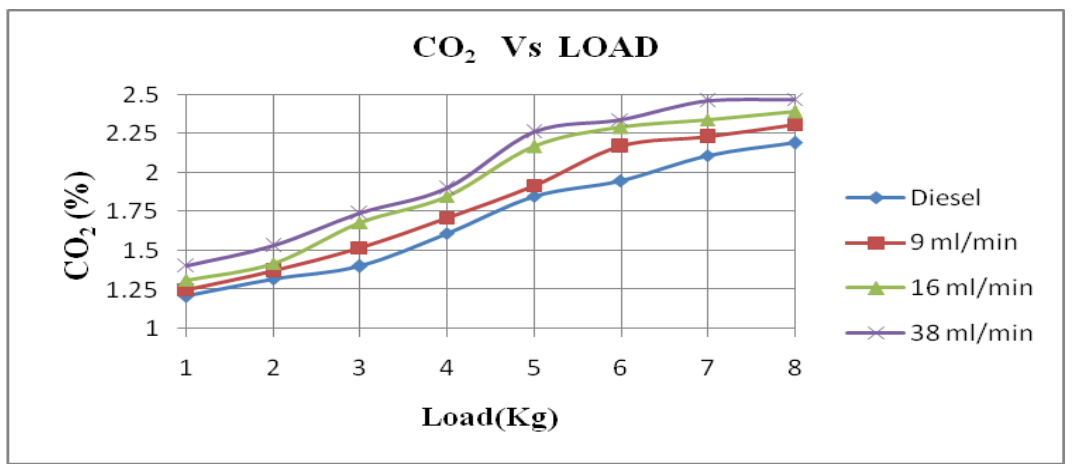

Fig.5 Comparison of $\mathrm{CO}_{2}$ level

The comparison of $\mathrm{CO}_{2}$ emission of different water flow rates and standard diesel engine is shown in fig-5. $\mathrm{CO}_{2}$ emission increase with water injection at all engine loads. The minimum $\mathrm{CO}_{2}$ emission is $1.25 \%$ at 1 $\mathrm{kg}$ at water injection conditions. Maximum increasement in $\mathrm{CO}_{2}$ emission is $0.28 \%$ at $8 \mathrm{~kg}$ load.

HC

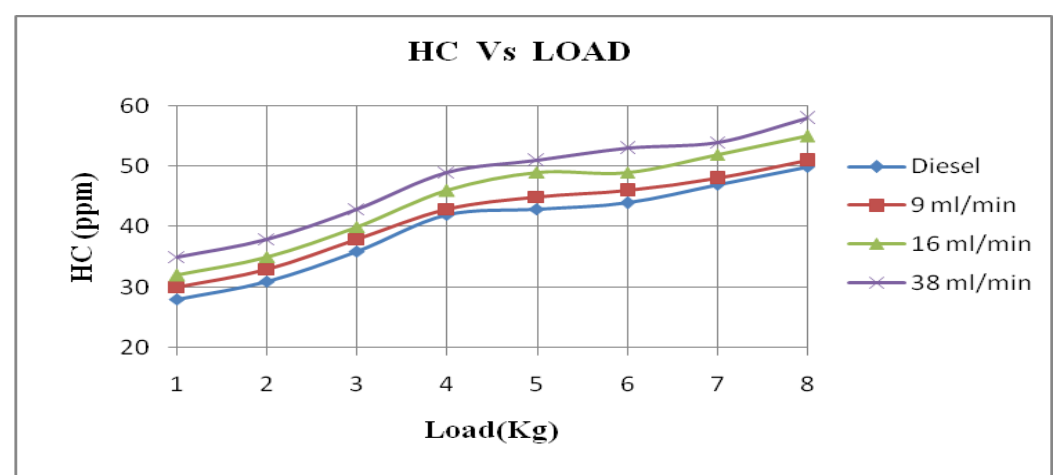

Fig.6 Comparison of HC level 
Fig-6 illustrates the comparison of $\mathrm{HC}$ emission of different water flow rate and standard diesel. The $\mathrm{HC}$ emission increase with water injection of $38 \mathrm{ml} / \mathrm{min}$ at 1 to $8 \mathrm{load}$. Minimum $\mathrm{HC}$ emission is $30 \mathrm{ppm}$ at $8 \mathrm{~kg}$ load of $9 \mathrm{ml} / \mathrm{min}$ water injection.

\section{Conclusion}

In this study the effects of manually controlled water injection system on emission have been investigated. There is an significantly decrease in formation of $\mathrm{NO}_{\mathrm{X}}$ at higher water flow rates, it also give negative effect on $\mathrm{CO}, \mathrm{CO}_{2}, \mathrm{HC}$ at all engine loads. Based on the experimental results the main effects of water injection are summarized as follows:

1) Water injection at intake manifold does not significantly affect cylinder pressure and heat release rate of CI engine operating with diesel. The results shows that water injection at the intake manifold affects the premixed combustion chamber which is mainly cause of $\mathrm{NO}_{\mathrm{X}}$ formation.

2) The water injection in to intake manifold reduces the $\mathrm{NO}_{\mathrm{X}}$ emission up to $46 \%$ over the entire load range but noticeable increase in $\mathrm{HC}$ and $\mathrm{CO}_{2}$. However $\mathrm{CO}$ emission increased by about $0.02 \%$ to $0.08 \%$.

3) Based on above it is conclude that water injection into the intake manifold has capability of reduce $\mathrm{NO}_{\mathrm{X}}$ emission with loss of power and has negative effect on specific fuel consumption.

\section{References}

[1] Exhaust odor and smoke reduction of stationary DI diesel engines to acceptable level by water-scrubbing and air-dilution system. www.elsevier.com/locate/apenergy,13 January 2011

[2] Theoretical and experimental investigation of diesel engine with steam injection system on performance and emission parameters. www.elsevier.com/locate/apthermeng, 9 February 2013

[3] Water-in-diesel emulsions and related systems, www.elsevier.com/locate/cis. Available online 27 June 2006.

[4] Effect of Diesel and Water Co-injection with Real-Time Control on Diesel Engine Performance and Emissions. SAE TECHNICALPAPER SERIES, 2008-01-1190.

[5] Nilamkumar s patel, Tushar m patel "performance characterization of single cylinder diesel engine fuelled with sesame oil - diesel and its blend with ethanol" Vol. 1 Issue 4, International Journal of Engineering Research \& Technology, ISSN: 2278-0181,June 2012 ..

[6] Hirenkumar m patel, Tushar m patel "Performance analysis of single cylinder diesel engine fuelled with Pyrolysis oil -diesel and its blend with Ethanol" Vol. 1 Issue 4, International Journal of Engineering Research \& Technology, ISSN: 2278-0181, June 2012 . 